\title{
Mild lead poisoning with an excessively high blood lead
}

\author{
M. J. CHAMBERLAIN and P. M. O. MASSEY \\ Dudley Road Hospital, Birmingham
}

\begin{abstract}
Chamberlain, M. J., and Massey, P. M. O. (1972). Brit. J. industr. Med., 29, 458-460. Mild lead poisoning with an excessively high blood lead. Lead poisoning occurred in a patient working as a smelter of precious metals on a process where lead was used as a substrate. Extremely high levels of blood lead up to $1050 \mu \mathrm{g} / 100 \mathrm{ml}$ were found despite only trivial clinical symptoms. Treatment consisted solely of removing the worker from the toxic environment. This resulted in complete recovery with return of the blood lead to a near normal value over the course of 12 months. Although there was only a mild anaemia present initially, the haemoglobin was slow to respond.
\end{abstract}

\section{Clinical details}

The patient, a man aged 44 years, had been employed on various tasks concerned with the 'cupellation' process described below, working for 11 years close to the furnaces. His normal working week was 44 hours. Apart from some lassitude towards the end of the day, nocturia present for two years, and occasional supra-orbital headache he was symptomfree. A blood lead of $1000 \mu \mathrm{g} / 100 \mathrm{ml}$ was recorded at laboratory $\mathrm{A}$ when blood was taken at the factory for routine examination after the occurrence of two other cases of lead poisoning at the same factory. A second sample taken at a surgery outside the factory, with no possibility of contamination, two weeks later had $1050 \mu \mathrm{g} / 100 \mathrm{ml}$ according to another laboratory (B). A third sample (taken in hospital) and estimated in laboratory B had $950 \mu \mathrm{g} / 100 \mathrm{ml}$. It forms the second point in the Figure. Two years previously the patient had attended his family doctor because of nausea and cramping colicky abdominal pain associated with certain foods. A barium meal examination had shown no abnormality and after three weeks away from work he had had no recurrence of symptoms. There had been no change in body weight.

On examination a doubtful blue line on the gum

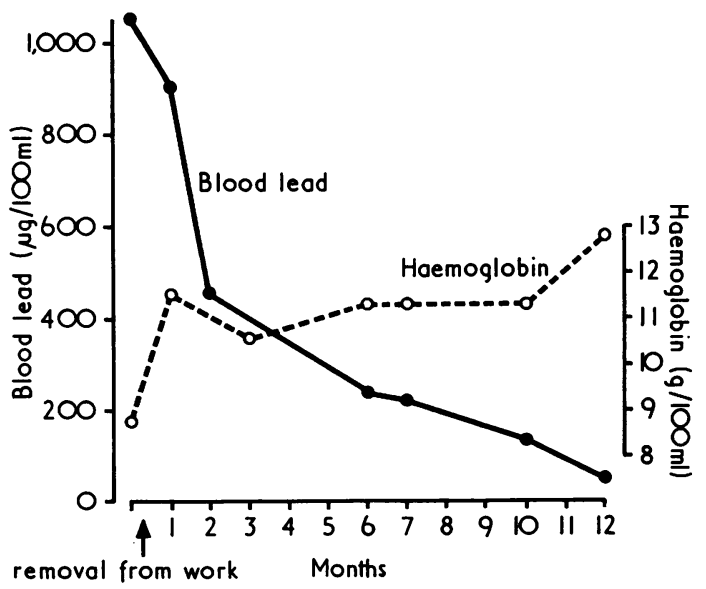

FIGURE Changes in blood lead and haemoglobin following removal from the toxic environment.

around several of the teeth in the lower jaw was the only physical abnormality. Oral hygiene was reasonably good but most of the molars had been extracted. He was not clinically anaemic and there was no muscular weakness or neurological defect. 


\section{Investigations}

Haemoglobin $11.5 \mathrm{~g} / 100 \mathrm{ml}$; basophilic stippling was evident on the stained film, reticulocyte count $7 \%$. Blood urea $24 \mathrm{mg} / 100 \mathrm{ml}$, creatinine clearance $137 \mathrm{ml} /$ minute. Total urinary protein $40 \mathrm{mg} / 24$ hours. There was no amino-aciduria nor glycosuria but there was failure to concentrate the urine after the administration of 5 units of pitressin tannate in oil. On admission to hospital the coproporphyrin III in the urine was normal, but six days later it had risen to $2000 \mu \mathrm{g} /$ litre.

\section{Progress}

In view of the trivial symptoms, absence of any evidence of incipient encephalopathy, and only minor anaemia and impairment of renal function, it was decided to treat simply by removal from the toxic environment. 'De-leading' with EDTA or penicillamine was not thought to be indicated in spite of the extreme elevation of the blood lead. Subsequent progress is shown graphically in the Figure, which illustrates the changes in haemoglobin and blood lead. After five months, the patient returned to work in the same factory (which had been closed for part of this time on account of this episode) but to a job which did not invoive exposure to lead. Twelve months after the diagnosis had been made the blood lead had fallen to $56 \mu \mathrm{g} / 100 \mathrm{ml}$, an acceptable figure for a lead worker (Davies, 1971), but the haemoglobin had risen to only $12.5 \mathrm{~g} / 100 \mathrm{ml}$. At this time he denied any symptoms.

\section{Process details}

The object of the process was the recovery of silver from various forms of scrap. Scrap film and photographic paper were burnt to give ash containing silver sulphide and carbon. This, together with other silver-containing residues, was charged into a smelting furnace together with litharge (lead oxide, $\mathrm{PbO}$ ), which was re-cycled from a refining furnace. Fluxing agents (sodium sulphate, borax, and fluorspar) and a little metallic lead were also added. The silver compounds and the litharge were reduced to a lead/ silver alloy which was cast into ingots. These were then charged into the refining furnace where they were melted. A stream of air was blown over the molten alloy and the lead was oxidized to litharge which rose to the top of the molten metal and was skimmed off as molten slag.

Lead oxide fume was evolved from both the smelting and the refining furnaces and, because of deficient exhaust ventilation, entered the atmosphere of the factory in copious quantities. Whilst charging the furnaces, personnel were breathing concentrations of atmospheric lead measured at up to $2.38 \mathrm{mg}$ per cubic metre. This compares with the accepted maximum permissible value of $0.2 \mathrm{mg}$ per cubic metre averaged over a 40-hour week. The only protection provided was a Martindale gauze mask. The deposit of dust around the plant was found to contain $25 \%$ lead.

\section{Discussion}

The absence of other than the most minor symptoms in spite of extreme elevation of the blood lead level was a striking feature of this case. The patient felt well and could see little reason to have further investigations in hospital, thereby jeopardizing his high wages. As Scott (1967) has shown, high blood lead levels are not in themselves indicative of the severity of the clinical condition or the need for urgent treatment but it must be admitted that the highest level to which he referred was no more than half of that found in the present case. Cantarow and Trumper (1944) state that the concentration of lead in blood bears no consistent relationship to the appearance or the severity of the clinical manifestations of lead poisoning. Hopkins (1970) induced experimental lead poisoning in baboons. The animals lost some weight but generally their health remained good despite blood lead levels up to 4550 $\mu \mathrm{g} / 100 \mathrm{ml}$ in some cases up to a year before death occurred with encephalopathy or renal failure.

Renal involvement in lead poisoning may be a major clinical factor and determinant of morbidity and mortality. The picture may be that of global renal failure with albuminuria, uraemia, and hypertension or that of a full-blown Fanconi syndrome (Emmerson, 1967). In the present case, failure to concentrate the urine in response to pitressin was the only element of a tubular syndrome present and the glomerular filtration rate was normal.

The anaemia was only mild at the time of diagnosis but it is of interest that it was slow to respond to treatment and remained present at 12 months. There was no evidence of blood loss to explain this, in that a barium meal was negative and occult blood could not be demonstrated in the stool.

The response of this case to simple removal from the toxic environment supports the view of Lane (1951) that active de-leading is in general to be avoided, especially in the absence of any neurological symptoms. It also emphasizes the value of control of atmospheric lead levels to well below the threshold value. Davies (1971) has advocated the regular determination of blood lead as an adequate screening process for lead workers with an indication to improve working conditions and practices if values higher than $60 \mu \mathrm{g} / 100 \mathrm{ml}$ are found. The monitoring of atmospheric lead levels and their control below threshold limits is equally important in view of the poor correlation of clinical symptoms with blood lead levels and the consequent difficulty in differentiating between lead exposure and lead poisoning. 


\section{References}

Cantarow, A., and Trumper, M. (1944). Lead Poisoning, p. 157. Williams and Wilkins, Baltimore.

Davies, M. H. (1971). The monitoring and control of industrial exposure to lead. Trans. Soc. occup. Med., 21, 126.

Emmerson, B. T. (1967). In Renal Disease, edited by D. A. K. Black, 2nd ed., pp. 561-579. Blackwell, Oxford.

Hopkins, A. (1970). Experimental lead poisoning in the baboon. Brit. J. industr. Med., 27, 130-140.
Lane, R. E. (1951). Lead poisoning. In The British Encyclopaedia of Medical Practice, edited by Lord Horder, 2nd ed., vol. 8, pp. 15-23. Butterworth, London.

Scott, T. S. (1967). Industrial medicine-an art or a science? Brit. J. industr. Med., 24, 85-92.

Received for publication January 22, 1972.

\title{
Glaucopsia-blue-grey vision
}

\author{
W. T. JONES and M. D. KIPLING \\ Information and Advisory Service, TUC Centenary Institute of Occupational Health, \\ London School of Hygiene and Tropical Medicine, and the Department of Employment
}

\begin{abstract}
Jones, W. T., and Kipling, M. D. (1972). Brit. J. industr. Med., 29, 460-461. Glaucopsia-bluegrey vision. Blue-grey vision due to the effect of certain amines on the eye is a recognized but generally little known phenomenon. We review previous accounts of the condition and describe our experience of its occurrences. We consider the condition should be known as 'glaucopsia'.
\end{abstract}

\section{Historical review}

At a meeting of the British Chemical Manufacturers, Amor (1949) drew attention to a blue haze caused by ethylamines in a Table illustrating the toxicity of solvents. This reference was later included in the Industrial Hazards Bulletin in Ethylamines of Imperial Chemical Industries Ltd. Mastromatteo (1965) found that in several places in Ontario, where morpholine, ethyl morpholine, methyl morpholine, and other heterocyclic amines were used as catalysts, the workers suffered from a condition described as 'halo', 'blue haze', or 'foggy vision'. In one workplace where recently foamed material was stored, all the workers were affected, the effect being particularly noticeable at the end of the shift. The author considered that the condition was not serious except inasmuch as it interfered with driving home after work. He attributed the condition to oedema of the cornea. Dernehl (1966) described blue haze as occurring in the vision of amine and foam plastic manufacturers, and Munn (1967) reported that he had seen cases caused by tertiary octylamine as well as diethylamine. In animal experiments, monobutylamine (Hanzlik, 1923), diisopropylamine (Treon, Sigmon, Kitzmiller, and Heyroth, 1949), and monoethylamine, diethylamine, and triethylamine, the latter three in concentrations of vapour as low as $50 \mathrm{ppm}$, were found to be irritants (Brieger and Hodes, 1951). Mellerio and Weale (1966) found that the instillation of n-ethyl piperidine, $n$-methyl morpholine, n-ethyl morpholine, tetramethyl ethylenediamine, and di-methylamine caused a haziness, irregularity, and sloughing of the corneal surface with violent desiccation. S. L. Miles (personal communication), by holding ethylamines below his eye, was able to produce on himself the effect that the atmosphere was full of blue cigarette smoke. One 